Bryant University

Bryant Digital Repository

Marketing Department Journal Articles

Marketing Faculty Publications and Research

Summer 2018

\title{
Socio-Economic Sourcing: Benefits of Small Business Set-Asides in Public Procurement
}

Timothy G. Hawkins

Naval Postgraduate School, timothy.hawkins@wku.edu

Michael J. Gravier

Bryant University, mgravier@bryant.edu

Wesley S. Randall

New College at Frisco

Follow this and additional works at: https://digitalcommons.bryant.edu/mark_jou

Part of the Business Administration, Management, and Operations Commons, Entrepreneurial and Small Business Operations Commons, and the Other Business Commons

\section{Recommended Citation}

Timothy Hawkins, Michael Gravier, Wesley S. Randall, (2018) "Socio-economic sourcing: benefits of small business set-asides in public procurement", Journal of Public Procurement, Vol. 18 Issue: 3, pp.217-239, https://doi.org/10.1108/JOPP-09-2018-014

This Article is brought to you for free and open access by the Marketing Faculty Publications and Research at Bryant Digital Repository. It has been accepted for inclusion in Marketing Department Journal Articles by an authorized administrator of Bryant Digital Repository. For more information, please contact dcommons@bryant.edu. 


\title{
SOCIO-ECONOMIC SOURCING: BENEFITS OF SMALL BUSINESS SET-ASIDES IN PUBLIC PROCUREMENT
}

\author{
Timothy Hawkins, Western Kentucky University \\ Michael Gravier, Bryant University \\ Wesley S. Randall, New College at Frisco
}

Published in Journal of Public Procurement, 18(3), 2018

Timothy Hawkins, Michael Gravier, Wesley S. Randall, (2018) "Socio-economic sourcing: benefits of small business set-asides in public procurement", Journal of Public Procurement, Vol. 18 Issue: 3, pp.217-239, https://doi.org/10.1108/JOPP-09-2018-014

\begin{abstract}
Small businesses are critical to economic health and encouraged in government spending by set-asides-annual small business sourcing goals that often are not attained. Little research has explored the negative and risky stigmas associated with small business sourcing. This research explores reduced transaction costs of small business sourcing to government buyers. A survey of 350 government source selections reveals lower transaction costs derived from lower perceived risk of receiving a bid protest and via more efficient source selection processes. Contrary to common bias, the performance level of small businesses is no less than that of large business. Thus, small businesses engender lower transaction costs for correcting supplier performance. Based on these findings, managerial and theoretical implications are discussed.
\end{abstract}




\section{SOCIO-ECONOMIC SOURCING: BENEFITS OF SMALL BUSINESS SET-ASIDES IN PUBLIC PROCUREMENT}

The Small Business Act of 1953 requires that a fair proportion of contract dollars be awarded, or set aside, to small businesses (Sakallaris, 2007). This is not a trivial directive as the public sector constitutes a huge market, approximately $\$ 2.7$ trillion annually in the U.S. alone (Bureau of Economic Analysis, 2017). This means that a tremendous amount of those public funds -- \$90.7 billion in fiscal year 2015 (FPDS-NG, 2015) -- is deliberately funneled to small businesses at all levels (municipal, county, state, and federal) as a matter of public policy aimed at achieving socio-economic benefits. The current, government-wide procurement goal stipulates that at least $23 \%$ of all federal government contracting dollars should be set aside for small businesses with targeted set asides for Women Owned Small Business (5\%), Small Disadvantaged Business (5\%), Service Disabled Veteran Owned Small Business (3\%), and Historically Underutilized Business Zones (3\%) (FPDS-NG, 2015).

Unfortunately, while the U.S. federal government annually seeks to award $23 \%$ of contract dollars to small businesses, it often fails to attain that goal (FPDS, 2005; FPDS, 2006; FPDS, 2007; FPDS, 2008; FPDS, 2009; FPDS, 2010; FPDS, 2011; FPDS, 2012; FPDS, 2013; FPDS, 2014; FPDS, 2015). Impediments to small business contracting include: contract bundling, strategic sourcing resulting in supplier rationalization, a lack of accountability for achieving socio-economic goals, a lack of small businesses in some industries, and many small businesses' lack of interest in government work (Grammich et al., 2011). Some have challenged whether the government really wants to meet the small business goals (Ivory, 2012). As Robert Burton, former acting administrator of the Office of Federal Procurement Policy states:

"Indeed, despite the fact that the federal government continues to channel procurement dollars (and perhaps even an increasing amount) to small businesses, the use of small businesses and the number of small business contract actions actually have declined. Consequently, it appears that federal procurement dollars are increasingly concentrated in a smaller number of small businesses" (2015 p.7-emphasis added).

Much of the blame derives from conflicting goals - a manifestation of the principle-agent problem endemic to public policy (c.f., Jensen and Meckling, 1976). Public policy promotes macro-level benefits on one 
hand; on the other hand, government agencies' primary concern is on the operational mission. Thus, government buyers often support small business goals only to the extent that they must comply with government regulations. At the operational level government buyers are more concerned with securing high-quality, reliable supplier performance, since the success of their missions hinges largely on suppliers. Adding to this issue is the fact that government buyers perceive performance risk in sourcing to small businesses (Ivory, 2012). Even major government suppliers, such as defense contractors, have expressed trouble obtaining quality bids for small business subcontracts (Grammich et al., 2011). Less research has investigated small business supplier perceptions, although it appears that small suppliers are discouraged from bidding on public contracts due to perceived - in many cases non-existent - stringent financial and performance standards (Withey, 2011).

The stated public policy of the United States is that the macro-level economy depends on the health of small businesses (15 USC §631). Specifically cited in this US law are the following justifications for small business set-asides: small businesses demonstrate reduced capability to compete in a free market economy due to several micro-economic or contract level factors including lack of access to capital, under-representation for trade negotiations, lack of access to information to compete successfully in international markets, increased discrimination (both because of their small size and because they are frequently owned by minorities), and suffering a disadvantage to compete against imports. Public law defines small businesses as "independently owned and operated and which is not dominant in its field of operation" (15 USC §632(a)(1)) referring to asymmetry in power between small businesses and non-small businesses.

These factors implicate transaction costs as perhaps the primary culprits in the under-utilization of small businesses by public procurement (Williamson, 1979). Two well-documented facets of supply management include ex ante fairness in supplier selection and ex post efficiency of quality supplier performance (Pearson and Ellram, 1995; de Boer et al 2001; Ho et al., 2010). While the former is more paramount in government sourcing, it is not unimportant to the private sector; fair selection and quality performance are intertwined. Both public and private-sector buyers labor to avoid adverse selection and moral hazard because they generate substantial 
transaction costs from vetting prospective suppliers ex ante and costs in monitoring supplier performance ex post (Caliendo et al., 2015; Mishra et al., 1998).

Despite the public policy focus on micro-level disadvantages, research has ignored them, especially in the context of small businesses. There are roughly 28 million small businesses in the U.S., yet they are often ignored, despite the fact that ignoring SMEs in research is "in fact totally inappropriate" (Spence and Lozano, 2000, p. 43). Our scan of the last ten years of the Journal of Small Business Management, Journal of Small Business Strategy, and Journal of Small Business and Entrepreneurship revealed only 48 business-to-business articles representing eight percent of all contributions. Most of these articles address various aspects of franchising. Furthermore, research in a business-to-government context is almost non-existent. Only one article (Albano et al., 2015) addressed any aspect of small businesses in the public sector.

The extent to which small business sourcing affects ex ante and ex post transaction costs is unknown. The purpose of this research, therefore, is to explore whether sourcing to small businesses offers lower transaction costs for government buyers. Given the challenges to government buyers, there may be unrealized transaction cost advantages to sourcing with small businesses (Albors-Garrigós et al., 2014; Barton and Thomas, 2009). Given the structural impediments to small business contracts and a lack of commitment to achieving small business goals, buyers may need intrinsic motives (Moore and Manring, 2009; Sanchis Llopis et al., 2015). Drawing upon transaction cost economics' theoretical foundation on institutions as the primary determinants of transaction costs (Coase, 1937; North, 1992; Williamson, 1979), we posit that the creation of institutions specific to small businesses will lead to reduced transaction costs for small businesses. In this role, transaction cost economics acts as the theoretical bridge connecting the macro-economic outcomes desired by public policy with micro-economic phenomena of buyer and supplier actions.

The remainder of this work is organized as follows. First, the study discusses the conceptual framework and proposed hypotheses regarding salient transaction costs in the context of small businesses in public procurement. Next, the study presents the research design and methodology, and then the study provides an 
analysis of the proposed model and reports the findings. Lastly, the study offers a summary discussion, including conclusions and implications. Findings contradict the published justification for set-asides: small businesses perform at the same level as large businesses, and consequently small businesses do not generate greater transaction costs in order to correct supplier performance.

\section{LITERATURE REVIEW}

\section{Background of Small Businesses and Socio-Economic Programs}

A major goal of the Small Business Administration (2010) is improving the economic viability of small business. Small businesses employ half the nation's workers. Secondly, small businesses provide significant employment opportunity and creation of strong middle class opportunities for America's workers (Neumark et al., 2011). Lastly, small businesses by their entrepreneurial nature, and by regulatory policy, provide access to employment and corporate ownership for individuals coming from historically underserved and underrepresented populations (Bates and Robb, 2014; Jennings, 2014; Qiao, et al., 2009; O'Hare, 1992).

Not only are socio-economic procurement programs important to the public sector (Denes, 1997), they are also critical to the private sector. Small businesses constitute approximately half of the private-sector economy and 99 percent of all businesses (SBA, 2012). They account for 90 percent of firms that export (Cullen, 2012) and develop 16 times more patents per employee than large patenting firms (Breitzman, 2008). Small and mediumsized enterprises (SME) are important to economic growth (Thurik and Wennekers, 2004; Wennekers and Thurik, 1999). SMEs outpace large businesses as measured by job creation, strategic flexibility, and innovation (Audretsch, 2007). Consequently, economies with more SMEs are more competitive and have higher growth rates than those with fewer SMEs (Audretsch et al., 2006).

At the macro-level, small and medium sized businesses are a fundamental element of health and economic viability of the United States (Sperling and Mills, 2012). According to the National Economic Council, over the past 20 years small and new businesses in the United States have been responsible for creating two out 
of every three net new jobs (Sperling and Mills, 2012). More specifically, small businesses are a foundational element to communities (i.e., populations less than 10,000 people) and play a significant role in the economic health of those communities (Yoshida and Deyle, 2005). These observations are not unique to the US but also occur in the European Union (Small businesses are also critical participants in the supply chain (Qi et al., 2014; Logozar, 2013). Evidence suggests that government procurement policy designed to shape competition can effectively create market structures conducive to dominant design cultivation (Wu, 2014).

The positive macro-level impacts of small business prompted the development of socio-economic programs by both government and private sectors to develop local economies, develop labor capabilities, and to expand their customer base. This macro strategy is well founded as "states with higher proportions of very small business employment do indeed experience higher levels of productivity growth, and Gross State Product growth, while having less wage inflation and lower unemployment rates" (Robbins et al., 2000, p. 293). Sourcing from small, minority-owned enterprises can increase job creation and economic development in distressed regions (Carter et al., 1999; Walker and Preuss, 2008). In turn, the income from these businesses and employees thereof expand the firm's customer base (Ram and Smallbone, 2003).

In order to achieve these macro-socioeconomic goals, several laws restrict micro-level transactions at the contract level. To attain the small business mandate, Federal Acquisition Regulation (FAR §19.502-2) requires that procurements less than 150 thousand dollars are automatically set aside for small businesses; moreover, the rule of two requires that requirements be set aside for small businesses if two or more small businesses can perform the work at market prices without compromising delivery and quality. These requirements limit competition for the federal contracting dollars to the pool of eligible small businesses. Private-sector firms performing government contracts often must comply with flow-down requirements to set aside commensurate portions of awarded subcontract dollars to small businesses. The primacy of these and other transaction-level constraints indicate that transaction costs drive outcomes for sourcing relationships in public procurement. 
An example of public procurement transaction costs are the fixed costs associated with regulation, which can have a disproportionate impact on small businesses (Calcagno and Sobel, 2014). At the same time, small business regulatory exemptions can make small business an attractive outsourcing partner for a large firm seeking to avoid such regulatory costs for certain none-core functions. For example, microfinance policy can have tremendous impact overcoming some of the historic barriers to female entrepreneurship (Laha and Kuri, 2014). Timely regulatory policy during business cycle downturn has a significant impact on a small businesses' ability to weather macro-business cycles (Alajoutsijärvi et al., 2012). Even areas such as infrastructure policy have a strong impact on small businesses success; Audretsch et al. (2015) found that small business startup activity is positively linked to infrastructure in general. All this evidence illuminates transaction costs distinctive to the context of public procurement and small businesses.

\section{Transaction Cost Economics (TCE)}

TCE theory explains the organization's boundaries (that is, size of the firm) by examining the transaction as the unit of analysis (Williamson, 1979). Transaction costs are the costs of running the system. When it is too costly to transact within the market (that is, outsource), the firm will make the product or service in its own hierarchy (Walker and Weber, 1984; 1987). Transaction costs are the costs of guarding against opportunism from trading partners. A behavioral assumption of TCE is bounded rationality (Simon, 1949) - the concept that there are limitations on human cognitions, and that humans cannot possibly know all the facts (Williamson, 1980). Contracts cannot be written that cover all possible contingencies; they are always incomplete. Thus, throughout the relationship, the parties will face opportunities to take advantage of one another - to behave opportunistically.

TCE theory suggests people will behave opportunistically when it is feasible and profitable (John, 1984). Importantly in relation to small businesses, the dominant principal-agent theoretical perspective finds that that sole owner and owner-operator businesses common in small businesses demonstrate more total value than 
entrepreneurs or managers of firms with outside equity claims - the former being partially the result of more efficient structure for the interactions between reduced agency costs and opportunism in the form of shirking and monitoring of labor (Jensen and Mecklin, 1976).

Thus, reliance on suppliers is costly in terms of preventing opportunism (for example, supplier monitoring costs, performance bonds, and contract formulation and negotiation costs). Due diligence in supplier selection is intended to mitigate the risk of adverse selection, but comes at a cost of personnel time and effort to collect and evaluate the requisite qualification and capability information. This information, in turn, helps buyers to mitigate risk. To the best of our knowledge, these ex-ante transaction costs for evaluating small businesses during the supplier selection process have never been quantified, and have never been compared to non-small business suppliers. Additionally, buyers who are obligated to set aside sourcing dollars for small businesses perceive greater transaction costs as a result, a fact which drives buyer behavior to reduce transaction costs by using a simplified source selection method (Abotsi et al., 2014; Edvardsson and Teitsdóttir, 2015; Rocha et al., 2015). Lastly, while a common paradigm is held among buyers that selecting small firms poses additional supplier performance risk (Ivory, 2012) as the final outcome (that is, greater transaction costs to rectify performance problems ex post), we find no extant empirical studies of this postulate. These insights are developed into the hypotheses that follow.

\section{Transaction Costs of Supplier Selection: Supplier Behavior}

A central tenet of a public contracting system is to maintain the public's trust via instilled integrity, fairness, and openness (Hawkins et al., 2016). One mechanism to ensure fairness and integrity in government sourcing is a bid protest - a written objection to a procedure or decision concerning supplier selection. A bid protest is a corrective mechanism to ensure integrity and fairness by providing an interested party to a procurement with a process to air complaints and obtain relief (Manuel and Schwartz, 2011). It is a written objection that can occur at any stage of the contract award process. Often, protests result from alleged errors or mistakes committed by the buying agency. The most common errors cited in protests are: poorly written or vague 
contract requirements; failure to follow the process or criteria laid out in the request for proposals; and failure to adequately document findings (GAO, 2014; Rumbaugh, 2010). A bid protest (termed a review in some governments) serves as an available remedy in nearly all governments' procurements worldwide (Melese et al., 2010).

Adjudicating these objections adds significant transaction costs to supplier selection procedures (Williamson, 1999) and delays the receipt of needed supplies and services (Schwartz et al., 2015). Bid protests traditionally result from alleged errors during source selections such as a failure to follow the evaluation criteria laid out in the request for proposals. Bid protests levy monetary and non-monetary costs resulting in: (1) suspension of performance for months (delays receipt of purchased goods and services), (2) reevaluating proposals, (3) paying proposal preparation costs and protest filing costs to the protester (lost agency funds), and (4) terminating an awarded contract and re-soliciting the project (a delay to the agency) (Rumbaugh, 2010). Thus, bid protests, while promoting fairness and transparency in the source selection process, pose significant problems for public buyers. These protests are quite effective; $43 \%$ are either sustained or withdrawn for corrective action (Schwartz et al., 2015). Consequently, agencies often simplify, and thereby sub-optimize, source selections in order to avoid bid protests, and these short cuts can degrade supplier performance (Hawkins et al., 2016).

In 2014 in the U.S., 2,135 federal procurements were protested (Schwartz et al., 2015). This number trended steeply upward from 2007-2011, then levelled. "From FY2008-FY2014 total government spending, adjusted for inflation, decreased 25\% while total protests increased 45\%" (Schwartz et al., 2015, p.8). When measured against the number of opportunities to protest from 2011 to 2013, the number of protests increased 29\% (Hawkins et al., 2016). Of those protest cases that made it to a decision from 2009-2014 (that is, the few that were not dismissed, settled, or withdrawn), only $17 \%$ were sustained, but an average of $42 \%$ of all protest cases were effective; they were either sustained or resulted in corrective action taken by the buying agency prior to a decision. Thus, bid protests can serve as an effective means for suppliers not selected for contract award to gain 
reconsideration. Further, the threat of bid protest guards against the government buyer's resistance to engage with small business.

Acquisition officials and end users loathe the receipt of a bid protest (Hawkins et al., 2016). Bid protests generate significant transaction costs and negatively impact operational capability (Melese et al., 2010). If filed prior to contract award, the agency must delay awarding a contract. If filed after contract award, the agency must direct the contractor to stop work pending resolution of the protest, which can take up to 100 days. The potential to receive a bid protest drives agencies to incur costs to: (1) prevent a protest (for example, thoroughly documenting and substantiating proposal evaluations and trade-off decisions), (2) defend against an actual protest lodged, and (3) take corrective actions. At best, an agency's voluntary corrective action means the competition is reopened, and proposals are allowed to be revised necessitating further evaluations and delaying the contract award. At worst, an authority such as the Government Accountability Office sustains the protest meaning that the procurement process must often start anew. This adds even more time and delays receipt of needed goods and services resulting in significant rework. The end users bear costs as well since their requirements are delayed or go unfulfilled. Bid protests are such a persistent concern that the U.S. Federal Government recently proposed legislation to impose a $\$ 350$ filing fee do dissuade frivolous protests (Poling, 2016).

\section{Bid Protests and Small Business}

Filing and adjudicating a bid protest follows a legal process (Bolton and Dewatripont, 2005). Legal counsel representing the interested party (that is, the protestor), although not required, is rarely absent. The government agency always involves its attorneys as a matter of policy. Evidence, statements of fact, and a memorandum of law are required, and sometimes the protest authority such as the Government Accountability Office or the Court of Federal Claims will host a hearing. Consequently, litigation costs are part of the process (Gordon 2013). Our search of one U.S. federal agency's contract award data for fiscal years 2010 and 2011 found two bid protest settlement costs of $\$ 50,000$ and $\$ 53,035.37$, respectively (FPDS-NG, n.d.). Another search of GAO bid protests revealed three decisions awarding the protestor $\$ 31,818.76$ (GAO, 2014), \$54,889.61 (GAO, 2014), and 
$\$ 259,488.52$ (GAO, 2016) for protest preparation costs and attorney's fees. Small businesses bear non-financial costs associated with lawsuits as well such as emotional costs, loss of business to competitors, and changes to firm structure (Klemm Analysis Group, 2005), which distract owners from strategic activities necessary to run their business.

In exploring the prospect of dissuading frivolous protests by imposing filing fees, Melese et al. (2010) found that the higher the cost of filing a bid protest, the less likely a firm will protest. In general, small businesses possess fewer financial resources than do large businesses (Barringer, 1997). By definition, small businesses have less revenue and, in some industries, fewer employees than do large businesses (lyer, 2015; Qi et al., 2014). Small businesses are also less sophisticated and less likely to employ staff attorneys (Frans and Meulenberg, 2004; Maser and Thompson, 2010) that can at least partially absorb the cost of preparing, filing, and defending a bid protest. They have lower overhead costs (St John and Heriot, 1993), and are less likely to have slack resources that can be dedicated to preparing a protest. They also have less experience (Barringer, 1997; Chen and Hambrick, 1995; Maser and Thompson, 2010), which manifests in a lower rate of sustained protests (Maser et al., 2010).

With evidence that small businesses possess less resources - a disadvantageous situation further aggravated by lower rates of sustained protests -- the costs associated with launching a protest should deter small businesses even more than large businesses. Therefore, source selections classified as a small business set aside should experience fewer protests, formally posited as:

\section{H1: Source selections that are set aside for small business and source selections that are protested will be negatively related.}

Due to the substantial transaction costs associated with a bid protest, government buyers assess the risk of negative outcomes associated with a protest a priori. Risk is defined as the product of the magnitude of consequences and the probabilities of occurrence (Ruefli et al., 1999; Svensson, 2000). Risks from protests include paying the protestor's preparation and legal costs, added time to complete the procurement, delays to the receipt of needed goods and services, additional effort and resources required to resolve the protest, rework in proposal 
evaluations, and shame and embarrassment experienced by the sourcing team (Combs et al., 2014; Hawkins et al., 2016). Protest may also bring negative career repercussions such as denying promotion or an admonishment. Protest risk is important because if the stakes are high, government buyers will take additional measures to avoid bid protests (Hawkins et al., 2016). Often, these additional measures increase transaction costs. One way government buyers attempt to reduce protest risk is to placate potential protesters. For example, building, fielding, and sustaining two varieties of Littoral Combat Ship substantially increased costs relative to doing so for a single ship (O'Rourke, 2014).

Another method to avoid bid protests relies on choosing sub-optimal source selection processes, such as minimizing negotiations or even employing a low-price, technically-acceptable (LPTA) source selection process when a full-tradeoff method is more appropriate (Gordon, 2013). In cases in which the source selection method used is inappropriate to the buying situation, supplier performance suffers (Hawkins et al. 2016). This is particularly relevant since poor supplier performance results in buyer transaction costs to detect and rectify the poor performance.

Another tactic to diminish bid protest risk consists of engaging in multiple rounds of negotiations that essentially level the playing field of competitors rather than providing clearer evaluation criteria up-front (Batra et al., 2015; Cramton, 1991; Doctoroff, 1998). This tactic frequently results in retaining mediocre suppliers in the consideration set, increasing the likelihood for a mediocre contractor to provide important outsourced goods and services to the government.

For many services, being classified as a small business is constrained by an annual revenue limit. For manufacturing, often the constraint is the number of employees. Compared to work not set aside for small businesses, in general, set-asides tend to be less complex, smaller-dollar efforts. Given the smaller efforts, often the associated magnitudes of negative consequences of a bid protest are lower. For example, the negative effects of a delay of a dormitory renovation due to a bid protest are likely much smaller than a delay to the production and delivery of new stealth bomber aircraft. 
Thus, we posit that:

H2: A buyer's perceived protest risk is lower for those procurements that are set aside for small businesses versus those that are not.

\section{Transaction Costs of Supplier Selection: Buyer Behavior}

Government buyers are often overworked (Mee, 2012), burdened by awarding and administering a substantial number of transactions. One way to ease the burden is to simplify the proposal evaluation process. Work that is set aside for small businesses may not be given the full respect it deserves. For example, it may be prudent in selecting a supplier to pay a higher price for higher past performance (that is, assurance of performance) or for higher technical capabilities, a superior technical approach, a stronger reputation, or for superior personnel qualifications - deemed a "full trade-off." However, a full-tradeoff requires substantially greater effort in documenting meaningful differences in proposals and in justifying paying a higher price (that is, higher transaction costs) and introduces substantially greater risk of making a mistake inviting a bid protest (even more transaction costs). To avoid these transaction costs, government buyers may take short cuts using an LPTA sourcing methodology in which the winner is determined by low price once pre-defined performance thresholds are met by offerors (Hawkins et al., 2016). Since the perceived risk of a protest is lower, government buyers may not invest as much due diligence in the source selection process. The source selection authority (that is, the decision maker) may be at a lower level in the organization. The source selection team size maybe smaller. The experience level of team members may be lower. The number of evaluation criteria may be fewer. The time allocated to complete the source selection may be less. This streamlined process should result in a simpler evaluation consuming less transaction costs.

Since small businesses do not have as much overhead and resources in general, their proposals are likely to be more streamlined and less elaborate than are those of large businesses. Thus, evaluations can be more efficient. As such, it is posited that:

H3: Transaction costs of supplier selections that are set asides for small business are lower than those that are not set aside for small businesses. 


\section{H4: The use of a simplified source selection method (LPTA) will be positively associated with small business set asides.}

\section{Supplier Performance Outcomes}

One important motive for the small business set-aside policy was to address perceived inability of small businesses to compete on price in order to integrate certain disadvantaged groups into the marketplace, even at the cost of economic efficiency (Krasnokutskaya and Seim, 2011; Marion, 2007). The perceived price inefficiency of small businesses results from several factors. A generally accepted economic argument proposes that interfering with free market forces distorts competition, violates law ${ }^{1}$ and increases costs-and some research finds evidence for increased costs (c.f., Marion, 2009; Ayres and Cramton, 1996). The perceived price inefficiency of small businesses results from several factors. Small businesses have less experience and this is perceived as an impediment to contracting (Van Den Top, 2009). Small businesses cannot obtain the same economies of scale as large businesses (Van Den Top, 2009), which also means that their input prices will be higher. Organizational buyers are also concerned that small businesses cannot secure funding needed to perform the contract (Van Den Top, 2009). Due to the lack of resources, small businesses are more likely to form cooperative arrangements (Street and Cameron, 2007). However, integrating performance across multiple firms and ensuring seamless quality performance may be seen by prospective buyers as risky.

Small businesses can have a stigma of not being able to perform as well as large businesses (Van Den Top, 2009) and may not have the same established reputation (Dean et al., 1998; Vossen, 1998); thus, they may be perceived as too risky to select for contract award. Large businesses may increase performance because they have access to more resources (Frans and Meulenberg, 2004) such as working capital; thus, they can render higher performance, and perhaps more importantly, muster the resources and influence to avoid instances of poor performance.

\footnotetext{
${ }^{1}$ The Competition in Contracting Act, 41 U.S.C. § 253(a) (2009) requires that "... an executive agency in conducting a procurement for property or services ... shall obtain full and open competition".
} 
However, outcomes of inclusion of small businesses appears to be highly contextual. Leaving aside the wider socio-economic benefits of encouraging a healthy population of SMEs in order to look only at discrete contract outcomes reveals that under the right circumstances there may be no distinguishable price penalty for small business participation in government contracting, and small business participation may often save the government money. Inclusion of small business drives down public bids in two important ways. Firstly, set-asides can bolster government bargaining power by increasing competition-an important benefit since many government contracting efforts suffer from diminished competition because of few qualified vendors (GAO, 2015). Evidence indicates that more of the "full" portion of "full and open" competition generates government cost savings simply by encouraging healthy bidding (Ayres and Cramton, 1996; Denes, 1997). Without set-asides, as many as $40 \%$ of SMEs would not participate in government bidding, increasing costs far greater than the differences in production inefficiency (Nakabayashi, 2013).

Large businesses can generate higher costs; indeed, excessive legal and administrative costs often deter SMEs from participating in public contract bids (Karjalainen and Kemppainen, 2008)-costs that larger businesses simply pass along to the government. When supplier performance is less than expected or required, buyers incur transaction costs. First, buyers invest heavily in oversight of suppliers to detect non-conformances, quality shirking, and other performance-threatening behaviors -- that is, avoiding moral hazards (Williamson, 1993). Second, buyers incur transaction costs to correct suppliers' performance problems. Corrective action could be as simple as providing direction, or may be more elaborate such as providing training, a lawsuit, or ultimately terminating a contract and re-sourcing the requirement. Third, large businesses have the clout to increase transaction costs for buyers through actions such as bid protests and ratings disputes-both mechanisms increasingly abused by larger businesses (Hawkins, et al., 2016), driving up costs of procurement.

Evidence indicates that the outcome of including small businesses in terms of performance in relation to cost depends on contextual factors, some of which fall under the buyer's influence. Where buyers make an effort to include small business and provide targeted support to address legal and administrative burdens, inclusion of 
small businesses can generate more competition from the inclusion of more bidders developing more innovations. Furthermore, small businesses incur lower transaction costs and may be more responsive to buyer feedback. These characteristics under some circumstances can override the advantages resident in large businesses. With equivocal empirical evidence, the following hypothesis should elucidate which circumstances dominate.

\section{H5: Performance levels for small business suppliers are greater than that of non-small business suppliers.}

\section{METHODOLOGY}

This study employed a survey to collect empirical data followed by quantitative analysis. The unit of analysis is a government source selection (that is, a competition among prospective suppliers). The remainder of this section details the survey development, pretest, the sample, data collection, and reliability and validity.

\section{Questionnaire Design and Construct Measurement}

Contractor performance is a measure of the contractor's performance levels and the degree to which requirements were satisfied. The scale was adapted from Fawcett, Smith, \& Cooper (1997), Cannon, Achrol, \& Gundlach (2000), and Prahinski \& Benton (2004). Protest risk consists of two parts since risk is comprised of the sum of the products of the magnitude of the consequences and the probability of occurrence. Questions assessed the desirability of each of five consequences of a protest and each of their associated probabilities of occurring. The five consequences were validated by interview informants to be those most likely to occur and those most abhorred. Risk was calculated by multiplying each consequence's probability of occurrence (rated 0 percent to 100 percent, in increments of 10 percent) by the desirability of the consequence (rated on a scale of -5 to 5 with anchors of completely undesirable and completely desirable, then converted to 1-11). The summed result yielded an overall protest risk score for each survey response. 
Transaction costs attempted to quantify the personnel costs based on amount of time spent on the source selection by each member of the buyer's source selection team. Transaction costs were calculated by asking respondents the number of people by role, pay grade, and fraction of one year's time spent on the source selection. The average 2013 General Schedule annual pay was used to calculate the cost for each role, and then summed for each source selection.

\author{
[Insert Table 1 about Here]
}

\title{
Sample
}

The population for this study consisted of U.S. civilian and military contracting personnel who had executed a formal source selection (i.e., a pre-award expected dollar amount greater than $\$ 150,000$ ). This excluded simplified procurements whose pre-award estimated value was expected to be less than $\$ 150,000$ that are generally less susceptible to bid protests. A list of e-mail addresses was generated using data extracted from the Federal Procurement Data System-Next Generation database to encompass all transactions that fit the criteria previously stated. Respondents were instructed to answer the survey questions using their experience from their most recently-completed formal source selection. The most recent source selection was required to serve as the basis of reference in order to prevent respondents' self-selection bias.

\section{Data Collection}

An online survey was used to collect the data. In order to maximize the response rate, we utilized Dillman's (2000) "Tailored Design Method" for internet surveys. A survey invitation was sent via e-mail to 3,882 contracting officers who had executed a formal source selection. There were 659 responses received, which yielded a $17 \%$ response rate. Of the responses received, 309 were deleted due to missing or obviously invalid data, leaving 350 usable responses. The final response rate of usable responses was $9 \%$.

The average respondent had 13.6 years of federal contracting experience. Male respondents accounted for 50.6 percent and female respondents accounted for 49.4 percent. Only $2.3 \%$ of respondents held only a high 
school diploma or general equivalency diploma, 3.14\% held an associate's degree, 38\% held a bachelor's degree, $54 \%$ held a master's degree, and $2.6 \%$ held a doctorate. The average number of protests experienced in a career by the respondent was 1.96 , and $15.4 \%$ of respondents had experienced a sustained protest. Small business set asides made up 42.6 percent (149) of the sample, while the remaining 57.4 percent (201) of source selections were not set aside. In the sample, 53 source selections were ultimately protested (15 percent). The median value of awarded contracts resulting from the source selections was $\$ 11,989,000$ (mean $=\$ 102,346,676 ; \min =\$ 102,000$; $\max =\$ 8,000,000,000)$. For the analysis of $\mathrm{H} 3$ testing for a difference in transaction costs, the sample size was substantially smaller due missing data. Complete data to calculate transaction costs was provided by 265 respondents.

[Insert Table 2 about Here]

\section{Reliability and Validity}

The reliability of the latent construct, contractor performance, was assessed using composite reliability (Fornell \& Larcker, 1981). At .96, it proved to be sufficiently reliable exceeding the minimum acceptable threshold of .70 (Nunnally, 1978). Construct validity was assessed via confirmatory factor analysis (CFA) in LISREL version 8.8. In the measurement model, the loading was significant at the .05 level, standard error was not abnormal; the standardized loading did not exceed 1.0, and no negative error variances (Heywood Cases) occurred. While the chi square statistic was significant (396.8 [308], $\mathrm{p}<.01$ ), the measurement model (CFA) exhibited acceptable fit. The TLI was .99, CFI was .99, AGFI was .90, RMSEA was .026, and the SRMR was .04.

The average variance extracted (AVE) of contractor performance at .81 exceeded the .50 standard, demonstrating convergent validity (Fornell and Larcker, 1981). We tested for non-response bias using Armstrong \& Overton's (1977) approach (Mullen et al., 2009). Responses were categorized into three groups according to the time received. Tests for differences in three latent constructs and two demographic variables revealed no significant differences, indicating a lack of response bias in the data. 


\section{RESULTS}

$\mathrm{H} 1$ posited that source selections that are set aside for small business and those that are protested will be negatively related. A chi square test of independence showed no association between protested source selections and small business set asides $\left(X^{2}=.02, p=.90\right)$; therefore, no support was found for $\mathrm{H} 1$.

H2 compared a buyer's perceived protest risk for those procurements that are set aside for small businesses versus those that are not. An independent samples t-test was significant $(t=-2.05, p<.05)$ revealing that protest risk is perceived to be lower for small business set asides (mean $=4.52$, std dev=2.38, range $=0-11$ ) than for procurements that are not set aside (mean $=5.05$, std dev=2.43, range=0-11). Thus, H2 was supported.

Next, ex ante transaction costs were examined. H3 posited that transaction costs of supplier selections that are set asides for small business are lower than those that are not set aside for small businesses. This difference was confirmed via ANOVA $(F=3.02, p=.08)$ with marginal significance. To ensure that the effect was not due to lower complexity or to a smaller scope of work associated with small business set asides, the dollar value of the contract was inserted as a control variable $(F=167.75, p<.01)$. The mean transaction cost of a source selection set aside for small business was $\$ 185,304.01$, while that of a non-set aside source selection was $\$ 276,679.70$. Thus, support was found for H3.

H4 explored why transaction costs are lower for small business set aside source selections. A chi square test of independence found that a simplified source selection method, LPTA, is indeed associated with small business set asides $\left(X^{2}=8.88, p<.01\right)$. Thus, $\mathrm{H} 4$ was supported.

Finally, H5 compared the levels of performance of procurements that were set aside for small business

versus those that were not set aside. An independent samples t-test revealed no difference $(t=.19, p=.85)$, providing insufficient evidence to support H5. Thus, it appears that there is no statistically significant performance difference between small and non-small businesses. 


\section{DISCUSSION}

The objective of this research was to explore whether sourcing to small businesses offers lower transaction costs for government buyers. This research is important because sourcing under socio-economic programs offers buying organizations relief in terms of lower transaction costs. The findings unveil specific sources of lower transaction costs and, importantly, find no support for a common bias against small businesses in government contracting. More specifically, procurement officials appear to under-estimate small business operational capabilities and their likelihood of filing a bid protest. The greater fear of bid protests from larger firms may drive procurement official behavior away from leveraging the lower transaction costs that our research found to be endemic from sourcing with small businesses. Our survey of 350 government source selections provided insights with significant managerial and theoretical implications.

\section{Implications for Practice}

First, contrary to that expected, setting aside a bid for small business sourcing does not diminish bid protests. Further research should explore whether small businesses feel just as comfortable as large businesses investing in a bid protest even with a moderate cost, or it may be that the set-aside program has served its purpose by equalizing the asymmetry in power between small and large businesses. Either case would demonstrate the efficacy of this public policy for achieving this particular goal. Meanwhile, government buyers should approach all source selections - those set aside and not set aside - with equal amounts of caution and due diligence. Following the very precise and lengthy procurement rules and regulations (that is, preventing a bid protest as best as possible) appears to be the best strategy for avoiding the additional transaction costs associated with adjudicating a bid protest.

Government buyers perceive lower protest risk from small business set asides; the result for $\mathrm{H} 1$ indicates that government buyers operate under an inaccurate assumption. Mistakenly perceiving lower risk, government buyers will be less apt to manipulate the sourcing strategy and selection process to avoid a bid protest. For 
example, the buyer is less likely to award more contracts than necessary thereby avoiding additional transaction costs of awarding and administering more contracts. And, the buyer is less likely to use an inappropriate source selection method (for example, LPTA rather than a full tradeoff of non-price factors with price). While the LPTA process is faster than a full trade-off selection process (that is, lower transaction costs), selecting the less optimal supplier because of rules prescribing the low bidder could result in lower performance (that is, higher transaction costs). Buyers could also be less likely to skip negotiations for fear of making a mistake. Of course, foregoing negotiations can result in paying higher prices resulting in higher transaction costs. The most important practitioner insight is that buyers need to be made aware of the actual risks of bid protests in order to for them to ascertain the most effective response.

Regardless of the accuracy of buyer perceptions, the selection process itself is more efficient when sourcing via small business set aside. On average, small business set asides consume $\$ 91,000$ less in transaction costs than do procurements not set aside, even after controlling for the effects of a less complex transaction. Government buyers may benefit from a streamlined source selection process. The source selection authority may be at a lower level in the organization permitting faster access to information sharing and decisions. The source selection team may be comprised of fewer people. Fewer evaluation criteria may need to be evaluated. In turn, suppliers' proposals will be shorter since they have less information to provide. Consequently, the overall time allocated to complete the source selection may be less. A streamlined process results in a simpler evaluation consuming less transaction costs. Thus, in cases in which buyers consider total costs of ownership rather than just purchase price in supplier selection, small businesses will have an additional cost advantage when the buyer factors in the transaction cost savings.

These soft transaction costs of conducting a source selection are not trivial. The average transaction cost of a source selection was $\$ 238,045$. Even though small business set asides generate an average of $\$ 91,000$ less in transaction costs, we found four cases in which the transaction cost exceeded the awarded contract value with an average excess of $\$ 143,268$. Thus, in a small number of cases, government agencies are spending more on 
selecting a supplier than on the goods and services being procured. Evidence from this study suggests that this may result from inaccurate perceptions by buying officials that small businesses are less likely to pursue a bid protest, which occur relatively seldom yet drive up transaction costs tremendously (Hawkins, et al., 2016).

Finally, this research finds a second buyer misperception while suggesting that public policy may succeed at leveling the playing field. As stated in the Small Business Act, small businesses suffer several disadvantages that directly impact their performance, including lack of access to information, increased discrimination, power asymmetry, and general competitive disadvantages derived from not being in a dominant economic position. This research found that small business suppliers performed just as well, meaning there is no added benefit to sourcing via small business set aside in terms of lower transaction costs associated with higher supplier performance (that is, less effort to correct performance defects). Nevertheless, a common belief among government buy-side acquisition teams and users of goods and services is that small business suppliers' performance is worse than that of large businesses (Ivory, 2012). Thus, while there is no transaction cost advantage, neither is there a transaction cost penalty. This finding is important since overcoming such a stigma can open the door for buyers to the other transaction cost efficiencies discovered herein. It is also critical to small businesses that must convince prospective buyers that they can indeed do the work and that transacting with them is without undue risk simply for being a small business. Interestingly, where past research into Finnish public procurement found that training can improve SME participation in public procurement (Saastamoinen, et al., 2017), it may be that government procurers could also benefit from training.

\section{Implications for Theory}

Past research has recommended TCE as the theoretical framework to explain the structure of the institutions and the governance mechanisms of supply chain transactions (Grover and Malhotra 2003; Vivek et al., 2008; Williamson, 2008). Transaction cost economic theory has been previously applied to understand bid protests in government procurements (Maser et al., 2012; Melese et al., 2010), yet few studies have assessed the 
interaction of regulatory-and specifically, socio-economic public policy-with transaction costs. Free markets would rely on the proper mix of contractual vs. relational mechanisms to deal with issues of opportunism and performance outcomes (Yang et al., 2012), whereas government procurement relies much more heavily on contractual mechanisms with limited options for relational adaptations to transactional needs. Our hypothesis that this would lead to reduced performance (H5) found no empirical support, suggesting that in the context of the heavily regulated and contractually governed public procurement arena, small businesses and government have developed alternative mechanisms to improve transaction cost efficiency while achieving performance standards.

Traditional TCE theory has focused on the institutional adaptation by firms along the spectrum of markets to hierarchies and the governance adaptation along the spectrum of contractual to relational (Williamson, 1979), with less attention paid to alternative forms of adaptation under conditions where institutional and governance options are limited, such as in public procurement. It appears that the choice (or mandate) of procurement dollars set aside for small businesses that transaction costs are lower, and are reduced in part by the use of simpler source selection methods and reduced risk of a bid protest. These results imply that the decision outcome of transactions along a spectrum of institutions or governance is more nuanced, with many adaptive outcomes possible at any point of the spectrum. If true, the implication is either than TCE has over-simplified the decision-making process regarding how to reduce transaction costs, or that a variable is missing. In the case of government procurement, the limited options for institutional and governance choices may be a tradeoff for reduced uncertainty in the source selection and contracting process; the open and transparent nature of public procurement may drive down uncertainty and reduce the costs of bounded rationality. The resulting contracts may be more complete, and both small businesses and public procurers benefit from more clearly stated expectations, where a relational governance response would generate greater transaction costs as the result of the effort required to maintain constant interactions and the uncertainty of future obligations, which would be a greater burden for a small 
business than for a large governmental organization. TCE variables of government and institutions may undervalue the importance of uncertainty.

An additional dimension may derive from the different transaction cost tradeoffs in government procurement; indeed, the area of quantifying the tradeoffs between the different transaction costs appears under-represented in extant research. Transaction costs fall into three broad categories: search and information costs associated with getting to know the market, bargaining costs to come to an agreement, and policing and enforcement costs after the agreement is made (Dahlman, 1979). Whereas non-governmental procurement often seeks to control costs of search and information uncertainty through relational mechanisms, governmental procurement depends almost entirely on competition. In the words of the Supreme Court, "the best method of allocating resources in a free market" and "all elements of a bargain--quality, service, safety, and durability--and not just the immediate cost, are favorably affected by the free opportunity to select among alternative offers" (National Society of Professional Engineers v. United States, 435 US 679, 1978). US policy creates a constructive tension with the canon of academic research that indicates that greater economic benefits result from greater cooperation (c.f., Lado, et al., 1997; Williamson, 1979). In the case of small businesses, the government policy of relying on competition creates a more stringent process that may compensate for increased search and information costs - and also at times great bargaining costs, especially in the case of a bid protest -by means of a fair and transparent sourcing process.

Socio-economic sourcing policies seek to achieve macro-economic benefits for society by mandating micro-economic behaviors. Based on the work of three Nobel-prize winning economists-Oliver Williamson, Ronald Coase for his eponymous 1937 paper, and Douglass C. North for applying economic theory to history-we posited the overwhelming importance of institutions for determining transaction costs (Coase, 1937; Williamson, 1979; North, 1992). Our findings confirm that transaction costs may be as much the result of, or at least are influenced by, micro-level factors. The theoretical implication: the mandate for small business set asides appears to reduce transaction costs by means of micro-economic individual behavior. Specific to the context of this study, 
institutional policies unique to small businesses appear to reduce transaction costs by shaping the contractual approach selected, the degree of complexity of the inter-organizational relationship, and ex post simplification of policing and enforcement due to a rigorous and transparent contract development process. More research should assess the transaction cost implications that result from individual buyer choice influence on the difference categories of transaction costs: search and information, bargaining costs, and policing and enforcement costs.

Finally, transaction cost economics failed to explain why source selections that are protested and source selections that are set aside for small business are not negatively related. Although bid protests increase transaction costs for all concerned, the burden would be disproportionately greater for small businesses, yet buys set aside for small businesses experience just as many bid protests. Various explanations may exist-perhaps the transaction cost of a bid protest is less than the cost for creating a new contract proposal to replace lost business, or given the misconception by buyers that the risk of protests is lower than it really is, perhaps buyers more often use an inappropriately simpler procurement approach for small business set asides that more often leads to grounds to protest.

\section{Study Limitations}

Limitations of this study, and those common to survey methodologies, should be considered. First, the response rate is remarkably low. However, it is not unlike that of other published business research. Melnyk et al. (2012) revealed a sharp decline in response rates starting in 2002 , with a steady decline of $1 \%$ annually. Five top journals reported low-end survey response rates ranging from $3 \%$ to $8 \%$. Survey length is thought to be one of the key contributors to the decline. This survey was necessarily lengthy, and parts of it involved consulting records rather than merely offering attitudes or opinions. Second, because this sample came solely from one military service, the extent of generalizability of the study findings to other government agencies is unknown. Third, the research design relied upon self-reported data from respondents introducing a threat of common method variance (CMV) (Podsakoff and Organ, 1986). Harman's one-factor test revealed that when all of the items were 
run in a single factor analysis, the unrotated solution did not result in a single factor, nor did it result in a general factor that accounted for most of the covariation (Podsakoff and Organ, 1986).

\section{Future Research Directions}

This research lays the foundation for meaningful and interesting small business research. The implications highlighted several findings worthy of future research. Additionally, future research could explore whether the same large business bias exists beyond the government sector. Are for-profit-sector buyers and users also reluctant to source via small businesses? Research could also explore whether the same effects on transaction costs occur among international governments' procurements. Future research could also explore other transaction costs following contract award. For instance, are small businesses more relational and trustworthy rendering the need for quality assurance and surveillance less? It would also be interesting to see how procurement official behavior changes when provided accurate information regarding lower transaction costs and risks of bid protests. Ultimately, future research should follow up on these findings to determine whether buyers erase the stigma of sourcing to small businesses. Will they give small businesses more opportunities to compete for challenging work? 


\section{TABLE 1}

\section{Latent Construct Measurement Scale}

\begin{tabular}{|c|c|c|}
\hline Label & Item & $\begin{array}{c}\text { Std. } \\
\text { Loading }\end{array}$ \\
\hline \multicolumn{3}{|c|}{ Contractor Performance* } \\
\hline \multicolumn{3}{|c|}{ On a scale of 1 to 7 , where 1 represents "needs improvement" and 7 represents "superior performance", rate the following. } \\
\hline $\mathrm{CP}^{1}$ & Product/service quality per specifications & .90 \\
\hline$C P^{2}$ & Delivery performance per specifications & .92 \\
\hline $\mathrm{CP}^{3}$ & Product/service consistently meets customer expectations & .92 \\
\hline$C P^{5}$ & Required service and/or technical support & .89 \\
\hline $\mathrm{CP}^{6}$ & Non-conformance rate & .80 \\
\hline $\mathrm{CP}^{7}$ & Overall performance & .94 \\
\hline \multicolumn{3}{|c|}{ Protest Risk } \\
\hline $\mathrm{PR}^{1}$ & Increased costs to settle a terminated contract(s). & N/A \\
\hline $\mathrm{PR}^{2}$ & Time delay to the mission. & N/A \\
\hline $\mathrm{PR}^{3}$ & Embarrassment/shame. & N/A \\
\hline $\mathrm{PR}^{4}$ & Increase in workload to resolve the protest. & N/A \\
\hline $\mathrm{PR}^{5}$ & Career repercussions for making a mistake or omission that caused a bid protest. & N/A \\
\hline
\end{tabular}

Notes: (1) All responses were obtained using 7-point Likert-type scales;

(2) * anchors of $1=$ needs improvement, $7=$ superior performance 


\section{TABLE 2}

Contract Type and Goods/Services Procured

\begin{tabular}{|c|c|c|c|}
\hline Contract Type & $\%$ of Total & $\begin{array}{ll}\text { Supply } & \text { or } \\
\text { Service } & \\
\text { Purchased } & \end{array}$ & $\%$ of Total \\
\hline Firm-Fixed Price & $60.00 \%$ & Services & $58.00 \%$ \\
\hline $\begin{array}{l}\text { Cost } \\
\text { Reimbursement }\end{array}$ & $27.14 \%$ & Construction & $16.86 \%$ \\
\hline Time \& Materials & $1.14 \%$ & $\begin{array}{l}\text { Supplies or } \\
\text { Commodities }\end{array}$ & $15.71 \%$ \\
\hline Labor-Hour & $0.57 \%$ & $\begin{array}{l}\text { Weapons } \\
\text { System }\end{array}$ & $6.57 \%$ \\
\hline Hybrid & $9.14 \%$ & $\begin{array}{l}\text { Other Capital } \\
\text { Equipment }\end{array}$ & $2.86 \%$ \\
\hline Other & $2.00 \%$ & & \\
\hline
\end{tabular}




\section{TABLE 3}

Construct Means, Standard Deviations, Scale Reliabilities, and Correlations.

\begin{tabular}{lccccc}
\hline & Mean & SD & Protest Risk & Performance & $\begin{array}{c}\text { Transaction } \\
\text { Costs }\end{array}$ \\
\hline Protest Risk & 4.83 & 2.42 & --- & & \\
Performance & 4.72 & 1.17 & -.06 & .96 & \\
Transaction & $\$ 238,045$ & $\$ 293,511$ & .09 & $-.17^{*}$ & --- \\
Costs & &
\end{tabular}

Notes: (1) Correlations are below the diagonal. (2) Composite reliability of the latent factor is on the diagonal. (3) *Significant, $p<.05$ 


\section{References}

Abotsi, A.K., Dake, G.Y., \& Agyepong, R.A. (2014). "Factors Influencing Risk Management Decision of Small and Medium Scale Enterprises in Ghana." Contemporary Economics, 8 (4): 397-413.

Alajoutsijärvi, K., Mainela, T., \& Ulkuniemi, P. (2012). "Dynamic Effects of Business Cycles on Business Relationships", Management Decision, 50 (2): 291-304.

Albano, G. L., Antellini Russo, F., Castaldi, G., \& Zampino, R. (2015). "Evaluating Small Businesses' Performance in Public e-Procurement: Evidence from the Italian Government's e-Marketplace." Journal of Small Business Management, 53 (October Supplement): 229-250.

Armstrong, J. S., \& Overton, T. S. (1977). "Estimating Nonresponsive Bias in Mail Surveys." Journal of Marketing Research, 14 (3): 396-402.

Albors-Garrigós, J., Rincon-Diaz, C.A., \& Igartua-Lopez, J.I. (2014). "Research Technology Organisations as Leaders of R\&D Collaboration with SMEs: Role, Barriers and Facilitators." Technology Analysis \& Strategic Management, 26 (1): 37-53.

Audretsch, D. B. 2007. The Entrepreneurial Society. Oxford: Oxford University Press.

Audretsch, D., Heger, D., \& Veith, T. (2015). "Infrastructure and Entrepreneurship." Small Business Economics, 44 (2): 219-30.

Audretsch, D. B., Keilbach, M. C., \& Lehmann, E. E. (2006). Entrepreneurship and Economic Growth. Oxford: Oxford University Press.

Ayres, I., \& Cramton, P. (1996). "Deficit Reduction through Diversity: How Affirmative Action at the FCC Increased Auction Competition." Stanford Law Review, 48 (April): 761-815.

Barringer, B. R. (1997). "The Effects of Relational Channel Exchange on the Small Firm: A Conceptual Framework." Journal of Small Business Management, 35 (2): 65-79.

Barton, R., \& Thomas, A. (2009). "Implementation of Intelligent Systems, Enabling Integration of SMEs to HighValue Supply Chain Networks." Engineering Applications of Artificial Intelligence, 22 (6): 929-38.

Bates, T., \& Robb, A. (2014). "Small-Business Viability in America's Urban Minority Communities." Urban Studies, 51 (13): 2844-62.

Burton, R. A. (2015). "Statement of Robert A. Burton Partner, Venable LLP, before the Committee on Small Business Small Business Subcommittee on Contracting and Workforce." United States House of Representatives, March 17, $2015 . \quad$ Retrieved 2 June 2016 from: http://smallbusiness.house.gov/uploadedfiles/3-17-2015 robert burton testimony.pdf.

Bureau of Economic Analysis (2017). National Income and Product Accounts, Table 3.1. Government Current Receipts and Expenditures. Retrieved 14 April 2017 from: https://www.bea.gov/iTable/index nipa.cfm.

Batra, S., Sharma, S., Dixit, M.R., Vohra, N., \& Gupta, V.K. (2015). "Performance Implications of Industry Appropriability for Manufacturing SMEs. "Journal of Manufacturing Technology Management, 26 (5): 66077.

Bolton, P., \& Dewatripont, M. (2005). Contract Theory, Cambridge, MA: Massachusetts Institute of Technology.

Breitzman, Anthony (2008). "An Analysis of Small Business Patents by Industry and Firm Size." Faculty Scholarship for the College of Science \& Mathematics. Paper 12. http://rdw.rowan.edu/csm facpub/12.

Calcagno, P., \& Sobel, R. (2014). "Regulatory Costs on Entrepreneurship and Establishment Employment Size." Small Business Economics, 42 (3): 541-59.

Caliendo, M., Hogenacker, J., Künn, S., \& Wießner, F. (2015). "Subsidized Start-Ups out of Unemployment: A Comparison to Regular Business Start-Ups." Small Business Economics, 45 (1): 165-90.

Cannon, J. P., Achrol, R. S., \& Gundlach, G. T. (2000). "Contracts, Norms, and Plural Form Governance." Journal of the Academy of Marketing Science, 28 (2): 180-94. 
Carter, C. R., R. J. Auskalnis, \& C. L. Ketchum (1999). "Purchasing from Minority Business Enterprises: Key Success Factors." Journal of Supply Chain Management, 35 (1): 28-32.

Chen, M., \& Hambrick, D. C. (1995). "Speed, Stealth, and Selective Attack: How Small Firms Differ," Academy of Management Journal, 38 (2): 453-482.

Combs, S., Calandruccio, J., \& Colbert, B. (2014). What are the Effects of Protest Fear? Monterey, CA: Naval Postgraduate School.

Cramton, P.C. (1991), "Dynamic Bargaining with Transaction Costs." Management Science, 37 (10): 1221.

Cullen, A. M. (2012). "The Small Business Set-Aside Program: Where Achievement Means Consistently Failing To Meet Small Business Contracting Goals." Public Contract Law Journal, 41 (3): 703-720.

Dahlman, Carl J. (1979). "The Problem of Externality." Journal of Law and Economics, 22 (1): 141-162.

De Boer, L., Labro, E., \& Morlacchi, P. (2001). "A Review of Methods Supporting Supplier Selection." European Journal of Purchasing and Supply Management, 7 (2): 75-89.

Dean, T. J., Brown, R. L., \& Bamford, C. E. (1998). "Differences in Large And Small Firm Responses to Environmental Context: Strategic Implications from a Comparative Analysis of Business Formations." Strategic Management Journal, 19 (8): 709-728.

Denes, T. A. (1997). “Do Small Business Set-Asides Increase the Cost of Government Contracting?" Public Administration Review, 57 (5): 441-444.

Dillman, D. A. 2000. Mail and Internet Surveys: The Tailored Design Method. 2nd Ed. New York, NY: John Wiley and Sons, Inc.

Doctoroff, S. (1998), "Reengineering Negotiations", Sloan Management Review, 39 (3): 63.

Edvardsson, I.R., \& Teitsdóttir, U.D. (2015). "Outsourcing and Financial Crisis: Evidence from Icelandic Service SMEs." Employee Relations, 37 (1): 30.

Fawcett, S. E., Smith, S. R., \& Cooper, M. B. (1997). "Strategic Intent, Measurement Capability, and Operation of Success: Making the Connection." International Journal of Physical Distribution and Logistics Management, 27 (7): 410-421.

Federal Procurement Data System - Next Generation (FPDS-NG).

Federal Procurement Data System (2005). "Small Business Goaling Reports," Retrieved 1 June 2016 from: https://www.fpds.gov/fpdsng cms/index.php/en/reports.html.

Federal Procurement Data System (2006). "Small Business Goaling Reports," Retrieved 1 June 2016 from: https://www.fpds.gov/fpdsng cms/index.php/en/reports.html.

Federal Procurement Data System (2007). "Small Business Goaling Reports," Retrieved 1 June 2016 from: https://www.fpds.gov/fpdsng cms/index.php/en/reports.html.

Federal Procurement Data System (2008). "Small Business Goaling Reports," Retrieved 1 June 2016 from: https://www.fpds.gov/fpdsng cms/index.php/en/reports.html.

Federal Procurement Data System (2009). "Small Business Goaling Reports," Retrieved 1 June 2016 from: https://www.fpds.gov/fpdsng cms/index.php/en/reports.html.

Federal Procurement Data System (2010). "Small Business Goaling Reports," Retrieved 1 June 2016 from: https://www.fpds.gov/fpdsng cms/index.php/en/reports.html.

Federal Procurement Data System (2011). "Small Business Goaling Reports," Retrieved 1 June 2016 from: https://www.fpds.gov/fpdsng cms/index.php/en/reports.html.

Federal Procurement Data System (2012). "Small Business Goaling Reports," Retrieved 1 June 2016 from: https://www.fpds.gov/fpdsng cms/index.php/en/reports.html.

Federal Procurement Data System (2013). "Small Business Goaling Reports," Retrieved 1 June 2016 from: https://www.fpds.gov/fpdsng cms/index.php/en/reports.html. 
Federal Procurement Data System (2014). "Small Business Goaling Reports," Retrieved 1 June 2016 from: https://www.fpds.gov/fpdsng cms/index.php/en/reports.html.

Federal Procurement Data System (2015). "Small Business Goaling Reports," Retrieved 1 June 2016 from: https://www.fpds.gov/fpdsng cms/index.php/en/reports.html.

Fornell, C., \& Larcker, D.F. (1981). "Evaluating Structural Equation Models with Unobservable Variables and Measurement Error." Journal of Marketing Research, 18 (February): 39-50.

Frans, J. H. M. V., \& Meulenberg, M. T. G. (2004). "Market Orientation, Innovativeness, Product Innovation, and Performance in Small Firms." Journal of Small Business Management, 42 (2): 134-154.

Gordon, D. I. (2013). "Bid Protests: The Costs are Real, but the Benefits Outweigh Them," Public Contract Law Journal, 42 (3): 489-516.

Government Accountability Office (2015). Federal Supply Schedules: More Attention Needed to Competition and Prices (GAO-15-590). Retrieved from http://www.gao.gov/products/GAO-15-590.

Government Accountability Office (2014). GAO Bid Protest Annual Report to Congress for Fiscal Year 2013 (GAO14-276SP). Retrieved from http://www.gao.gov/assets/660/659993.pdf.

Government Accountability Office (2014). 6K Systems, Inc.--Costs (B-408124.6). [Online]. Available at http://www.gao.gov/products/D09553.

Government Accountability Office (2014). Intermarkets Global--Costs (B-400660.14). [Online]. Available at http://www.gao.gov/products/B-400660.14.

Government Accountability Office (2016). Federal Builders, LLC-The James R. Belk Trust--Costs (B-409952.3). [Online]. Available at http://www.gao.gov/products/B-409952.3.

Grammich, C.A., Edison, T., Moore, N.Y., \& Keating, E.G. (2011). Small Business and Defense Acquisitions: A Review of Policies and Current Practices. Santa Monica, CA: RAND Corporation, National Defense Research Institute.

Grover, V., \& Malhotra, M. K. (2003), "Transaction Cost Framework in Operations and Supply Chain Management Research: Theory and Measurement." Journal of Operations Management, 21 (4): 457-473.

Hawkins, T. G., Gravier, M. J., \& Yoder, E. C. (2016). “Federal Bid Protests: Is the Tail Wagging the Dog?” Journal of Public Procurement, 16 (2): 152-190.

Ho, W., Xu, X., \& Dey, P. K. (2010). "Multi-Criteria Decision Making Approaches for Supplier Evaluation and Selection: A Literature Review." European Journal of Operational Research, 202 (1): 16-24.

Ivory, D. (2012). "Small Businesses Short-Changed on U.S. Contracts for 10 Years," Bloomberg (March 29), http://www.bloomberg.com/news/articles/2012-03-29/small-businesses-short-changed-on-contractsfor-10-years-1-.

Iyer, R. (2015). "House Small Business Committee Hearing." Lanham: Federal Information \& News Dispatch, Inc.

Jennings, L. (2014). "Do Men Need Empowering Too? A Systematic Review of Entrepreneurial Education and Microenterprise Development on Health Disparities among Inner-City Black Male Youth." Journal of Urban Health, 91 (5): 836-50.

Jensen, M. C., \& Meckling, W. H. (1976). "Theory of the Firm: Managerial Behavior, Agency Costs and Ownership Structure." Journal of Financial Economics, 3 (4), 305-360.

John, G. (1984). "An Empirical Investigation of Some Antecedents of Opportunism in a Marketing Channel." Journal of Marketing Research, 21 (3): 278-289.

Karjalainen, K., \& Kemppainen, K. (2008). "The Involvement of Small- and Medium-Sized Enterprises in Public Procurement: Impact of Resource Perceptions, Electronic Systems and Enterprise Size." Journal of Purchasing and Supply Management, 14 (4): 230-240. 
Klemm Analysis Group (2005). Impact of Litigation on Small Business. Washington, D.C. Retrieved online on June 22, 2016 at: https://www.sba.gov/sites/default/files/files/rs265tot.pdf.

Krasnokutskaya, E., \& Seim, K. (2011). "Bid Preference Programs and Participation in Highway Procurement Auctions." American Economic Review, 101 (6): 2653-2686.

Laha, A., \& Kuri, P.K. (2014). "Measuring the Impact of Microfinance on Women Empowerment: A Cross Country Analysis with Special Reference to India." International Journal of Public Administration, 37 (7): 397-408.

Lado, A. A., Boyd, N. G., \& Hanlon, S. C. (1997). "Competition, Cooperation, and the Search for Economic rents: A Syncretic Model." Academy of Management Review, 22 (1): 110-141.

Manuel, K. M., \& Schwartz, M. (2011). GAO Bid Protests: An Overview of Time Frames and Procedures (R40228). Retrieved from https://www.fas.org/sgp/crs/misc/R40228.pdf.

Marion, J. (2007). "Are Bid Preferences Benign? The Effect of Small Business Subsidies in Highway Procurement Auctions." Journal of Public Economics, 91 (7): 1591-1624.

Marion, J. (2009). "How Costly is Affirmative Action? Government Contracting and California's Proposition 209." Review of Economics and Statistics, 91 (3): 503-522.

Maser, S., \&Thompson, F. (2010). Understanding and Mitigating Protests of Department of Defense Acquisition Contracts. (WIL-CM-10-164). Salem, OR: Atkinson Graduate School of Management, Willamette University.

Maser, S., Subbotin, V., \& Thompson, F. (2010). The GAO's Bid-Protest Mechanism: Effectiveness and Fairness in Defense Acquisitions? Salem, OR: Atkinson Graduate School of Management, Willamette University, Retrieved from http://ssrn.com/abstract=1616424http://ssrn.com/abstract=1616424.

Maser, S., Subbotin, V., \& Thompson, F. (2012). "How Bid-Protest Mechanisms Mitigate Opportunism In Government Contracting." International Public Management Journal, 15 (2): 137-159.

Mee, K. (2012). "Improving Opportunities for Women-Owned Small Businesses in Federal Contracting: Current Efforts, Remaining Challenges, and Proposals for the Future." Public Contract Law Journal, 41 (3): 721 743.

Melese, F., Angelis, D., \& LaCivita, C.J. (2010). A New Paradigm to Address Bid Protests. (NPS-CM-10-159). Monterey, CA: Naval Postgraduate School.

Melnyk, S. A., Page, T. J., Wu, S. J., \& Burns, L. A. (2012). "Would You Mind Completing this Survey: Assessing the State of Survey Research in Supply Chain Management." Journal of Purchasing and Supply Management, $18(1): 35-45$.

Mishra, D.P., Heide, J.B., \& Cort, S.G. (1998). "Information Asymmetry and Levels of Agency Relationships." Journal of Marketing Research, 35 (3): 277.

Moore, S.B., \& Manring, S.L. (2009). "Strategy Development in Small and Medium Sized Enterprises for Sustainability and Increased Value Creation." Journal of Cleaner Production, 17 (2): 276-82.

Mullen, M. R., Budeva, D. G., \& Doney, P. M. (2009). "Research Methods in the Leading Small BusinessEntrepreneurship Journals: A Critical Review with Recommendations for Future Research." Journal of Small Business Management, 47 (3): 287-307.

Nakabayashi, J. (2013). "Small Business Set-asides in Procurement Auctions: An Empirical Analysis." Journal of Public Economics, 100: 28-44.

Neumark, D., Wall, B., \& Zhang, J. (2011). "Do Small Businesses Create More Jobs? New Evidence for the United States from the National Establishment Time Series." The Review of Economics and Statistics, 93 (1): 1629.

Nicholas, C., \& Fruhmann, M. (2014). "Small and Medium-Sized Enterprises Policies in Public Procurement: Time for a Rethink?" Journal of Public Procurement, 14 (3), 328-360. 
North, Douglass C. 1992. "Transaction Costs, Institutions, and Economic Performance." San Francisco, CA: ICS Press.

Nunnally, J. C. (1978). Psychometric Theory (2nd ed.), New York: McGraw-Hill.

O'Hare, W. (1992), "Reaching for the Dream." American Demographics, 14 (1): 32.

Oni, O., \& Papazafeiropoulou, A. (2014). "Diverse Views on It Innovation Diffusion among SMEs: Influencing Factors of Broadband Adoption." Information Systems Frontiers, 16 (4): 729-47.

O'Rourke, R. (2014). Navy Littoral Combat Ship (LCS) Program: Background and Issues for Congress (RL33741). Retrieved from http://www.fas.org/sgp/crs/weapons/RL33741.pdf.

Pearson, J. N., \& Ellram, L. M. (1995). "Supplier Selection and Evaluation in Small versus Large Electronics Firms." Journal of Small Business Management, 33 (4): 53-65.

Podsakoff, P. M., \& Organ, D. W. (1986). "Self-Reports in Organizational Research: Problems and Prospects." Journal of Management, 12 (4): 531-544.

Poling, S.A. (2016). "Government Accountability Office, Administrative Practice and Procedure, Bid Protest Regulations, Government Contracts." Federal Register. Retrieved online on June 22, 2016 at: https://www.federalregister.gov/articles/2016/04/15/2016-08622/government-accountability-officeadministrative-practice-and-procedure-bid-protest-regulations.

Prahinski, C., \& Benton, W. C. (2004). "Supplier Evaluations: Communication Strategies to Improve Supplier Performance." Journal of Operations Management, 22 (1): 39-62.

Qi, Z., Hong, L., \& Xiaoxiao, Q. (2014). "Research on Small and Medium Enterprises Financing Mode Based on Supply Chain Finance." Journal of Chemical \& Pharmaceutical Research, 6 (5): 1818-24.

Qiao, Y., Thai, K. V., \& Cummings, G. (2009). "State and Local Procurement Preferences: A Survey." Journal of Public Procurement, 9 (3/4), 371-410.

Ram, M., \& D. Smallbone (2003). "Supplier Diversity Initiatives and the Diversification of Ethnic Minority Businesses in the UK." Policy Studies, 24 (4): 187-204.

Robbins, D.K., Pantuosco, L.J., Parker, D.F., \& Fuller, B.K. (2000). "An Empirical Assessment of the Contribution of Small Business Employment to U. S. State Economic Performance." Small Business Economics, 15 (4): 293302.

Rocha, V., Carneiro, A., \& Varum, C.A. (2015), "Entry and Exit Dynamics of Nascent Business Owners." Small Business Economics, 45 (1): 63-84.

Ruefli, T.W., Collins, J.M., \& Lacugna, J.R. (1999). "Risk Measures in Strategic Management Research: Auld Lang Syne?" Strategic Management Journal, 20 (2): 167.

Rumbaugh, M. G. (2010). Understanding Government Contract Source Selection. Vienna, VA: Management Concepts.

Saastamoinen, J., Reijonen, H., \& Tammi, T. (2017). "The Role of Training in Dismantling Barriers to SME Participation in Public Procurement." Journal of Public Procurement, 17 (1), 1-30.

Sakallaris, A.G. (2007). "Questioning The Sacred Cow: Reexamining The Justifications For Small Business Set Asides." Public Contract Law Journal, 36 (4): 685-700.

Sanchis Llopis, J.A., Millán, J.M., Baptista, R., Burke, A., Parker, S.C., \& Thurik, R. (2015). "Good Times, Bad Times: Entrepreneurship and the Business Cycle." International Entrepreneurship and Management Journal, 11 (2): 243-51.

Schwartz, M., Manuel, K. M., \& Martinez, L. P. (2015). GAO Bid Protests: Trends and Analysis (R40227). Retrieved from https://www.fas.org/sgp/crs/misc/R40227.pdf. 
Spence, L. J., \& Lozano, J.F. (2000). "Communicating about Ethics with Small Firms: Experiences from the U.K. and Spain," Journal of Business Ethics, 27 (1/2): 43-53.

Sperling, G.B., \& Mills, K.G. (2012). "Moving America's Small Businesses \& Entrepreneurs Forward: Creating and Economy Built to Last." Washington, DC: National Economic Council, The White House.

St John, C. H., \& Heriot, K. C. (1993). "Small Suppliers and JIT Purchasing." International Journal of Purchasing and Materials Management, 29 (1): 11-16.

Street, C. T., \& Cameron, A. (2007). "External Relationships and the Small Business: A Review of Small Business Alliance and Network Research." Journal of Small Business Management, 45 (2): 239-266.

Svensson, G. (2000). "A Conceptual Framework for the Analysis of Vulnerability in Supply Chains." International Journal of Physical Distribution \& Logistics Management, 30 (9): 731-49.

Thurik, R., \& Wennekers, S. (2004). “Entrepreneurship, Small Business and Economic Growth." Journal of Small Business and Enterprise Development, 11 (1): 140-149.

U.S. Small Business Administration (2010), The State of Small Business: A Report to the President. Washington D.C.: Small Business Administration.

U.S. Small Business Administration (2012). Small Business Economy 2012. Downloaded 5 Jun 15 from: https://www.sba.gov/sites/default/files/files/Small Business Economy 2012(2).pdf.

Van Den Top, T. A. (2009). Small Business Programs: Benefits, Barriers, Bridges and Success Factors. WrightPatterson AFB, OH: Air Force Institute of Technology, retrieved online June 20, 2016 from: http://oai.dtic.mil/oai/oai?verb=getRecord\&metadataPrefix=html\&identifier=ADA501282.

Vivek, S., Banwet, D. K., \& Shankar, R. (2008). "Analysis of Interactions among Core, Transaction and RelationshipSpecific Investment: The Case of Off Shoring." Journal of Operations Management, 26 (2): 180-197.

Vossen, R. W. (1998). "Relative Strengths and Weaknesses of Small Firms in Innovation." International Small Business Journal, 16 (3): 88-94.

Walker, G., \& Weber, D. (1984). "A Transaction Cost Approach to Make-or-Buy Decisions." Administrative Science Quarterly, 29 (3): 373-91.

Walker, G., \& Weber, D. (1987). "Supplier Competition, Uncertainty, and Make-or-Buy Decisions." Academy of Management Journal, 30 (3): 589-586.

Walker, H., \& Preuss, L. (2008). "Fostering Sustainability through Sourcing from Small Businesses: Public Sector Perspectives." Journal of Cleaner Production, 16 (15): 1600-1609.

Wennekers, S., \& Thurik, R. (1999). "Linking Entrepreneurship and Economic Growth." Small Business Economics, 13 (1): $27-56$.

Williamson, O.E. (1979). "Transaction Cost Economics: The Governance of Contractual Relations." Journal of Law and Economics, 22 (2): 233-61.

Williamson, O. E. (1980). "The Organization of Work: A Comparative Institutional Assessment." Journal of Economic Behavior and Organization, 1 (1): 5-38.

Williamson, O. E. (1993). “Opportunism and Its Critics." Managerial and Decision Economics, 14 (2): 97-107.

Williamson, O. E. (2008). "Outsourcing: Transaction Cost Economics and Supply Chain Management." Journal of Supply Chain Management, 44 (2): 5-16.

Withey, J. J. (2011). "Small Manufacturing Businesses: Their Interest in Securing Contracts from Public Agencies." Journal of Public Procurement, 11 (3), 388-402.

Wan, R. (2014). "Public Procurement of Innovation Policy: Competition Regulation, Market Structure and Dominant Design." Journal of Public Procurement, 14 (4), 473-494. 
Yang, C., Wacker, J. G., \& Sheu, C. (2012). "What Makes Outsourcing Effective? A Transaction-Cost Economics Analysis." International Journal of Production Research, 50 (16): 4462-4476.

Yoshida, K., \& Deyle, R.E. (2005). "Determinants of Small Business Hazard Mitigation." Natural Hazards Review, 6 (1): 1-12. 